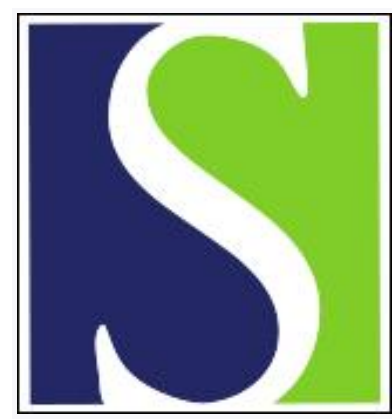

Scand J Work Environ Health 1982;8(4):290-293

https://doi.org/10.5271/sjweh.2464

Issue date: Dec 1982

Increase of sister chromatid exchange and unscheduled synthesis of deoxyribonucleic acid by acrylonitrile in human lymphocytes in vitro.

by Perocco P, Pane G, Bolognesi S, Zannotti M

This article in PubMed: www.ncbi.nlm.nih.gov/pubmed/7170626

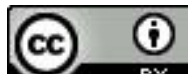




\title{
Increase of sister chromatid exchange and unscheduled synthesis of deoxyribonucleic acid by acrylonitrile in human lymphocytes in vitro
}

\author{
by Paolo Perocco, MS, ${ }^{1}$ Gianluigi Pane, MS, ${ }^{2}$ Silvana Bolognesi, BSc, ${ }^{1}$
} Maria Zannotti, MS ${ }^{2}$

\begin{abstract}
PEROCCO P, PANE G, BOLOGNESI S, ZANNOTTI M. Increase of sister chromatid exchange and unscheduled synthesis of deoxyribonucleic acid by acrylonitrile in human lymphocytes in vitro. Scand $j$ work environ health 8 (1982) $290-293$. The investigation has been carried out on cultures grown in the presence of $5 \times 10^{-1}-5 \times 10^{-5} \mathrm{M}$ acrylonitrile with or without a rat liver metabolizing system (S-9 mix). The results obtained showed that acrylonitrile was toxic starting from the $5 \times 10^{-3} \mathrm{M}$ concentration, caused a significant increase in the sister chromatid exchange (SCE) frequency in comparison with the controls ( $p \leq 0.001$ ) when the concentration was $5 \times 10^{-4} \mathrm{M}$, and elicited reparative deoxyribonucleic acid (DNA) synthesis, determined by tritiated thymidine uptake, particularly when the concentration was $5 \times 10^{-1} \mathrm{M}$. These effects were observed in lymphocytes of different donors and after drug activation by the S-9 mix metabolizing system.
\end{abstract}

Key terms: chemical mutagenicity, deoxyribonucleic acid repair, plastics industry monomers.

Some monomers utilized in the plastics industry show mutagenic and carcinogenic properties either towards bacterial cells and experimental animals or directly towards man. These properties are well known for the halogenated vinyl monomers and for other chemically related molecules. However, limited experimental data are available for many of these substances despite their wide industrial use.

Acrylonitrile $\left(\mathrm{CH}_{2}=\mathrm{CHCN}\right.$, vinyl cyanide, cyano-ethylene, propenenitrile) belongs to this class of compounds. This monomer is widely used as an intermediate in the manufacture of synthetic fibers, plastics, and rubbers and as a grain fumigant, and it has been shown to have mutagenic power in assay systems utiliz-

${ }^{1}$ Institute for Cancer Research, University of Bologna, Bologna, Italy.

2 Institute of Histology and General Embryology, University of Bologna, Bologna, Italy.

Reprint requests to: Dr P Perocco, Istituto di Cancerologia, Viale Filopanti, 22, I-40126 Bologna, Italy. ing bacterial cells $(7,17)$ and carcinogenic activity in animals $(6,15,16)$. Furthermore, acrylonitrile is toxic and a suspected carcinogen to man (4), even if negative results have been obtained concerning its genotoxic action in cytogenetic studies on mice and rats (11) and in epidemiologic investigations carried out with exposed workers (14)

In this study additional data are reported on the damaging actions of this substance on deoxyribonucleic acid (DNA) and its mutagenic effect on human lymphocytes cultured in vitro in the presence (treated) or absence (controls) of three scalar doses of acrylonitrile.

The parameters studied were (i) the scheduled DNA synthesis (replicative synthesis), (ii) the unscheduled DNA synthesis (reparative synthesis) in cultures grown in the presence of hydroxyurea, and (iii) the frequency of sister chromatid exchanges.

Scheduled and unscheduled DNA syntheses were measured through the tritiated 
thymidine uptake by lymphocytes, and all the experiments were carried out with or without metabolic activation of the drug.

\section{Materials and methods}

\section{Lymphocyte cultures}

The experimental conditions have been previously described $(9,12)$. Briefly, 50$60 \mathrm{ml}$ of blood from healthy adult donors was collected, and lymphocytes were separated according to Böyum (1). Lymphocytes, $2 \times 10^{5} /$ well of microtest culture plate, were cultured in a volume of $0.2 \mathrm{ml}$ of Roswell Park Memorial Institute (RPMI) 1640 medium, supplemented with $2 \mathrm{mM}$ glutamine and containing $0.25 \mu \mathrm{Ci}(9,250$ $\mathrm{Bq}$ ) of tritiated thymidine $\left({ }^{3} \mathrm{H}-\mathrm{TdR}\right)$ (The Radiochemical Centre, Amersham, England).

Cultures were grown for $4 \mathrm{~h}$ at $37{ }^{\circ} \mathrm{C}$ in humidified atmosphere containing $5 \%$ carbon dioxide in the absence (controls) or presence of acrylonitrile in concentrations of $5 \times 10^{-1}$ to $5 \times 10^{-3} \mathrm{M}(99 \%$ purity; Merck-Schuchardt, Darmstadt, Federal Republic of Germany).

Toxic effects of the drug were measured by the ${ }^{3} \mathrm{H}-\mathrm{TdR}$ uptake for the DNA scheduled synthesis.

To study the action of acrylonitrile as a DNA-damaging agent, the ${ }^{3} \mathrm{H}$-TdR uptake for the unscheduled DNA synthesis was measured by the addition of $10 \mathrm{mM}$ hydroxyurea (Sigma, St Louis, MO, USA) to the cultures to block the DNA replicative synthesis $(3,5)$.

The metabolic activation of the drug was obtained through a phenobarbital-induced rat liver metabolizing system (S-9 $\mathrm{mix}$ ) as previously described (9).

At the end of the culture periods, ${ }^{3} \mathrm{H}-\mathrm{TdR}$ uptake to determine the scheduled or the unscheduled DNA syntheses, in sextyplicate wells for each experimental combination, was measured by a liquid scintillation spectrometer as previously described (12), and it was exposed in disintegrations per minute \pm standard error.

\section{Sister chromatid exchange frequency}

Whole blood from healthy adult donors was cultured at $37^{\circ} \mathrm{C}$ in RPMI 1640 medium supplemented with $10 \%$ human pooled sera in the presence of phytohe- moagglutinin (Difco, Detroit, MI, USA) and bromodeoxyuridine (BUdR) (Sigma) in concentrations of 1 and $10 \mu \mathrm{g} / \mathrm{ml}$, respectively.

Acrylonitrile, or only medium to the controls, was added to the cultures for $1 \mathrm{~h}$ at $48 \mathrm{~h}$ of incubation at concentrations ranging from $5 \times 10^{-3}$ to $5 \times 10_{-5}^{-5} \mathrm{M}$ in the presence or absence of S-9 mix. Thereafter, the culture tubes were centrifuged, the supernatants were discarded, and the cells were suspended in fresh BUdR-containing medium.

Cultures, carried out under dim light, were stopped at $72 \mathrm{~h}$ and colcemid $(0.2 \mu \mathrm{g} /$ $\mathrm{ml}$ ) (CIBA, Basel, Switzerland) was added for the last $2 \mathrm{~h}$ of culture.

After hypotonic treatment with $0.075 \mathrm{M}$ potassium chloride, air-dried preparations of chromosomes were obtained by the standard procedure. The staining technique used was essentially according to Schneider et al (13) and the fluorescence plus Giemsa method of Perry \& Wolff (10); the slides were stained with Hoechst 33258 $(15 \mu \mathrm{g} / \mathrm{ml})$ in $50 \mathrm{mM}$ phosphate buffer $(\mathrm{pH}$ 6.8) for $15 \mathrm{~min}$, rinsed, mounted in $50 \mathrm{mM}$ citric acid-100 mM phosphate buffer ( $\mathrm{pH} 7$ ), and exposed to a $100-\mathrm{W}$ visible-light lamp from a distance of $6 \mathrm{~cm}$ for $2 \mathrm{~h}$. The slides were rinsed and stained with $3 \%$ Giemsa in $50 \mathrm{mM}$ phosphate buffer $(\mathrm{pH} 6.8)$ for $15 \mathrm{~min}$. For each experimental combination 20 metaphases with $\geq 44$ chromosomes were scored for sister chromatid exchanges. The differences in the means of the treated and control groups were analyzed by Student's t-test $(2 \mathrm{p})$.

\section{Results and discussion}

Fig 1 reports the values for the ${ }^{3} \mathrm{H}-\mathrm{TdR}$ uptake in the cultures of lymphocytes from two different donors treated with three doses of acrylonitrile, plus untreated controls, for $4 \mathrm{~h}$ in the presence or absence of $10 \mathrm{mM}$ hydroxyurea and S-9 mix. It appears that acrylonitrile is toxic at high doses, ie, $5 \times 10^{-1}$ and $5 \times 10^{-2} \mathrm{M}$, in cultures grown without metabolic activation, as shown by the low ${ }^{3} \mathrm{H}$-TdR uptake in comparison with that of the controls (dotted line in figure). On the contrary, the ${ }^{3} \mathrm{H}-\mathrm{TdR}$ uptake was significantly higher than that of the controls, particularly in $5 \times 10^{-1} \mathrm{M}$ acrylonitrile-treated cultures grown in the presence of S-9 $\mathrm{mix}$. 
If the presence of hydroxyurea (which inhibits scheduled DNA synthesis) is taken into account, we can argue that these high values of thymidine uptake are due to

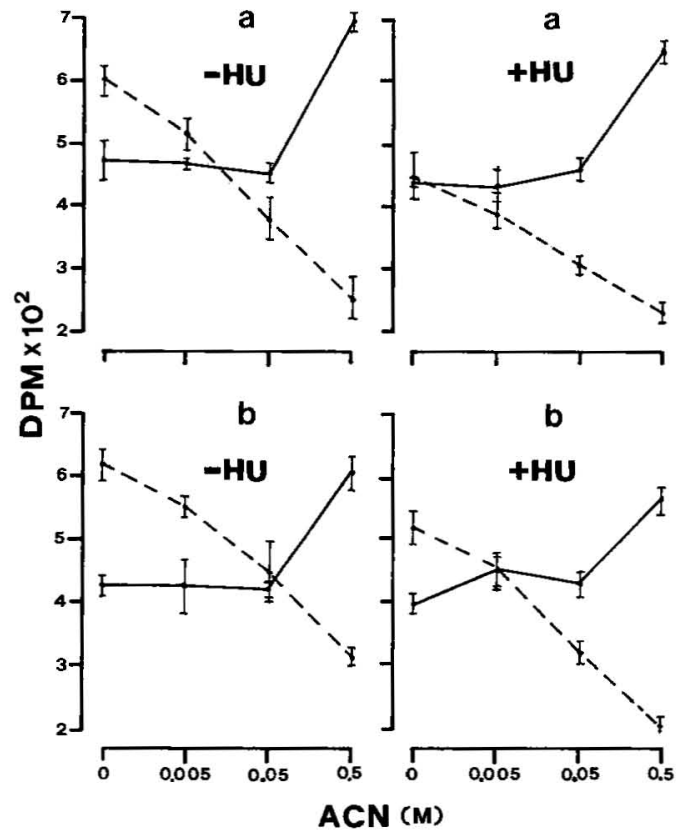

Fig 1. Tritiated thymidine uptake by human lymphocytes from two different donors $(a, b)$. The lymphocytes were cultured in vitro for $4 \mathrm{~h}$ in the presence or absence (controls) of acrylonitrile (ACN) with (-) or without (- .- - -) S-9 mix metabolizing system and $10 \mathrm{mM}$ hydroxyurea $( \pm \mathrm{HU})$. Data, in disintegrations per minute, are the means of sextuplicate samples \pm standard error. unscheduled DNA synthesis after metabolic activation of the drug to a DNA-damaging form.

These toxic and mutagenic actions of acrylonitrile are confirmed by the sister chromatid exchange assay reported in table 1 . In fact, a small but statistically significant increase $(p \leq 0.001)$ of sister chromatid exchange frequency in comparison with that of the controls has been obtained for human lymphocytes from two different donors after treatment with $5 \times$ $10^{-4} \mathrm{M}$ acrylonitrile for $1 \mathrm{~h}$ with metabolic activation.

The sister chromatid exchange frequency following treatment with $5 \times 10^{-3} \mathrm{M}$ acrylonitrile could not be determined because only few cells with pycnotic nuclei and without mitotic figures were observable.

The frequency of sister chromatid exchange obtained with $5 \times 10^{-5} \mathrm{M}$ acrylonitrile was not significantly different from that of the controls, either with or without the metabolic activation of the drug.

These results are in agreement with those reported in the literature. In fact, the DNA-damaging and mutagenic activities of acrylonitrile towards human lymphocytes confirm the toxic, teratogenic, and carcinogenic power observed for this substance in studies carried out on rodents $(6,15,16)$ and its mutagenic effects towards mammalian and bacterial cells cultured in vitro $(7,8,17)$.

Table 1. Sister chromatid exchange (SCE) frequency in human lymphocytes from two different donors $(a, b)$. The lymphocytes were cultured in vitro for $1 \mathrm{~h}$ in the presence or absence (controls) of acrylonitrile with or without the S -9 mix metabolizing system. Significance has been calculated by the Student's t-test.

\begin{tabular}{|c|c|c|c|c|c|c|}
\hline \multirow{2}{*}{$\begin{array}{l}\text { Acrylonitrile } \\
\text { doses (M) }\end{array}$} & \multicolumn{3}{|c|}{$-S-9$ mix } & \multicolumn{3}{|c|}{$+\mathrm{S}-9$ mix } \\
\hline & SCE/cella & $t^{b}$ & $p$-value & SCE/cella & to & $p$-value \\
\hline \multicolumn{7}{|l|}{ Donor a } \\
\hline $\begin{array}{l}5 \times 10^{-5} \\
5 \times 10^{-4} \\
5 \times 10^{-3}\end{array}$ & $\begin{array}{c}8.15 \pm 0.44 \\
8.75 \pm 0.54 \\
-d\end{array}$ & $\begin{array}{l}0.6 \\
0.3 \\
-\end{array}$ & $\begin{array}{l}\text { NSc } \\
\text { NS } \\
-\end{array}$ & $\begin{aligned} 8.30 & \pm 0.61 \\
11.10 & \pm 0.53 \\
& \end{aligned}$ & $\begin{array}{l}0.4 \\
3.8 \\
-\end{array}$ & $\begin{array}{c}\text { NS } \\
p<0.001 \\
-\end{array}$ \\
\hline Control & $8.55 \pm 0.38$ & & & $7.95 \pm 0.62$ & & \\
\hline \multicolumn{7}{|l|}{ Donor $b$} \\
\hline $\begin{array}{l}5 \times 10^{-5} \\
5 \times 10^{-4} \\
5 \times 10^{-3}\end{array}$ & $\begin{array}{c}7.40 \pm 0.50 \\
8.50 \pm 0.55 \\
-\end{array}$ & $\begin{array}{l}0.1 \\
1.3 \\
-\end{array}$ & $\begin{array}{c}\text { NS } \\
\text { NS } \\
-\end{array}$ & $\begin{aligned} 8.90 & \pm 0.55 \\
10.80 & \pm 0.69 \\
& -\end{aligned}$ & $\begin{array}{c}1.4 \\
3.5 \\
-\end{array}$ & $\begin{array}{c}\text { NS } \\
p=0.001 \\
-\end{array}$ \\
\hline Control & $7.50 \pm 0.46$ & & & $7.85 \pm 0.44$ & & \\
\hline
\end{tabular}

a Mean of $\mathbf{2 0}$ metaphases scored \pm standard error.

Treated/control groups.

c Not statistically significant.

d No visible metaphases. 
Our results also confirm that acrylonitrile needs metabolic activation by S- 9 mix to exert its highest mutagenic power, as reported in previous studies utilizing the Ames Salmonella/microsome test (7) and in investigations carried out in vitro on the metabolic pathways of acrylonitrile (2). However, this substance was also found to be a directly acting mutagen for some strains of Escherichia coli, and it has been suggested that this action could be due to a peculiar sensitivity of these bacteria to mutagenic chemicals (17).

The toxic and mutagenic actions of acrylonitrile were observable only at very high doses, which varied in the two experimental conditions. This discrepancy might be ascribed to genetic damage induced by different mechanisms and/or sensitivity of the tests.

The disagreement between the significance of the sister chromatid exchange frequency observed in this study and the lack of chromosome aberrations in lymphocytes of acrylonitrile-exposed workers (14) is probably due to differences in experimental conditions and acrylonitrile doses ( $<20 \mathrm{ppm}$ for the exposed workers).

As far as we know, no data are available in the literature on the mutagenic action exerted by this chemical directly on human cells. On the other hand our results were obtained with concentrations which are not comparable with those of workplaces. However, if the massive production and use of acrylonitrile are taken into account, it cannot be excluded that genotoxic effects could be determined in man by a prolonged and continuous exposure to this substance.

\section{Acknowledgments}

This investigation was supported by grant $500.4 / \mathrm{RSC} / 135 / \mathrm{L} / 1208$ from the Ministero della Sanitá.

The authors are grateful to Dr F Cappi, director of the Centro Regionale per il Servizio Trasfusionale - U.S.L. 27 Bologna Ovest, for the human blood supply.

\section{References}

1. Böyum A. Separation of leukocytes from blood and bone marrow. $J$ clin lab invest 21 (1968): suppl 97, 77-82.

2. Duverger-Van Bogaert M, Lambotte-Van- depaer M, De Meester C, Rollmann B, Poucelet F, Mercier M. Effect of several factors on the liver extract mediated mutagenicity of acrylonitrile and identification of four new in vitro metabolites. Toxicol lett 7 (1981) 311-318.

3. Evans RG, Norman A. Radiation stimulated incorporation of thymidine into the DNA of human lymphocytes. Nature 217 (1968) 455-456.

4. International Agency for Research on Cancer Working Group on the Evaluation of the Carcinogenic Risk of Chemicals to Humans. Some monomers, plastics and synthetic elastomers, and acrolein. Lyon 1979, pp 73-113. (IARC monographs on the evaluation of the carcinogenic risk of chemicals to humans, volume 19).

5. Lieberman MW, Baney RN, Lee RE, Sell S, Farber E. Studies on DNA repair in human lymphocytes treated with proximate carcinogens and alkylating agents. Cancer res 31 (1971) 1297-1306.

6. Maltoni C, Ciliberti A, Di Maio V. Carcinogenicity bioassay on rats of acrylonitrile administered by inhalation and by ingestion. Med lav 68 (1977) 401-411.

7. Milvy $P$, Wolff $M$. Mutagenic studies with acrylonitrile. Mutat res 48 (1977) 271-278.

8. Parent RA, Casto BC. Effect of acrylonitrile on primary Syrian golden hamster embryo cells in culture: Transformation and DNA fragmentations. J natl cancer inst 62 (1979) 1025-1029.

9. Perocco P, Prodi G. DNA damage by haloalkanes in human lymphocytes cultured in vitro. Cancer lett 13 (1981) 213-218.

10. Perry P, Wolff S. New Giemsa method for the differential staining of sister chromatids. Nature 251 (1974) 156-158.

11. Rabello-Gay MN, Ahmed AE. Acrylonitrile: In vivo cytogenetic studies in mice and rats. Mutat res 79 (1980) 249-255.

12. Rocchi P, Perocco P, Alberghini W, Fini A, Prodi G. Effect of pesticides on scheduled and unscheduled DNA synthesis of rat thymocytes and human lymphocytes. Arch toxicol 45 (1980) 101-108.

13. Schneider EL, Tice RT, Kram D. Bromodeoxyuridine differential chromatid staining technique: A new approach to examining sister chromatid exchange and cell replication kinetics. Methods cell biol 20 (1978) 379-409.

14. Thiess AM, Fleig I. Analysis of chromosomes of workers exposed to acrylonitrile. Arch toxicol 41 (1978) 149-152.

15. US Consumer Produced Safety Commission. Assessment of acrylonitrile contained in consumer products, final report. Washington, DC 1978.

16. US Department of Labor. Occupational exposure to acrylonitrile (vinyl cyanide): Proposed standard and notice of hearing. Fed regist 43 (1978) 2586-2621.

17. Venitt S, Bushell CT, Osborne M. Mutagenicity of acrylonitrile (cyanoethylene) in Escherichia coli. Mutat res 45 (1977) 283288.

Received for publication: 9 June 1982 